\title{
НОВЫЕ ИНИЦИАТИВЫ РОССИИ ПО ПРИВЛЕЧЕНИЮ ЗАРУБЕЖНЫХ ИНВЕСТИЦИЙ В РАЗВИТИЕ ЭКОНОМИКИ ДАЛЬНЕГО ВОСТОКА
}

Чжон Мен Су (Jeon Myong Su) - управляющий ООО «Рус экономик», г. Владивосток (e-mail: russiaeconomic@gmail.com)

Трофименкова E.B. (Trofimenkova E.V.) - кандидат экономических наук, доцент кафедры экономики и управления, Владивостокский государственный университет экономики и сервиса, 690014, Российская Федерация, г. Владивосток, ул. Гоголя, 41 (e-mail: trofimenkova08@mail.ru)

\section{Аннотация.}

Российский Дальний Восток является регионом с высоким инвестиционным потенциалом для сотрудничества с Республикой Корея. От величины потенциала зависит конкурентоспособность региона. Определенно, чем выше эта величина, тем больше у региона предпосылок для эффективного экономического развития. В статье рассмотрены факторы, сдерживающие социально-экономическое развитие региона, и основные показатели, характеризующие инвестиционную привлекательность Дальнего Востока. Применение новой национальной программы «Социальноэкономическое развитие Дальнего Востока на период до 2024 года и на перспективу до 2035 года» создаст на Дальнем Востоке глобально конкурентоспособные условия для зарубежных инвестиций и ведения бизнеса.

Ключевые слова: валовый региональный продукт, сотрудничество, Дальний Восток, социально-экономическое развитие, инвестиционная привлекательность, национальная программа.

Стратегическое развитие экономики регионов Дальнего Востока требует повышения интенсивности инвестиционного процесса. Привлечение реальных инвестиций необходимо в целях своевременного обновления технологической базы производства и внедрения инноваций. Иными словами, повышение инвестиционной привлекательности региона является одной из ключевых задач пространственного экономического развития

Дальневосточный регион России характеризуется богатством природных ресурсов, наличием многоотраслевой экономики. Макрорегион имеет выгодное геополитическое положение, граничит с быстроразвивающимся Азиатско-Тихоокеанским регионом, общий объем выпуска продукции (ВВП) которого находится в пределах 50 трлн. долларов 
(около 65\% мирового ВВП). Азиатско-Тихоокеанский регион обладает широким рынком сбыта продукции, ежегодный объем импорта которого составляет 6 трлн. долларов.

Несмотря на наличие таких широких экономических возможностей, российский Дальний Восток слабо интегрирован в экономику стран АТР. Валовой региональный продукт (ВРП) Дальневосточного региона составляет 56 \% совокупного ВРП по субъектам РФ, это около 50 млрд. долларов (табл. 1).

Таблица 1 - ВРП Дальнего Востока в структуре ВРП по субъектам РФ

\begin{tabular}{|c|c|c|c|c|c|c|c|}
\hline Показатели & 2000 г. & 2004 г. & 2008 г. & 2012 г. & 2016 г. & 2017 г. & 2018 г. \\
\hline $\begin{array}{l}\text { ВРП по } \\
\text { субъектам РФ } \\
\text { (валовая } \\
\text { добавленная } \\
\text { стоимость } \\
\text { текущих } \\
\text { ценах) - всего, } \\
\text { трлн. руб. }\end{array}$ & 5753,6 & 13964,3 & 33908,7 & 49926,1 & 69237,7 & 74798,9 & 84976,7 \\
\hline $\begin{array}{lr}\text { ВРП Дальнего } \\
\text { Востока } \\
\text { текущих } \\
\text { ценах, } \\
\text { руб. } \\
\text { трлн. } \\
\end{array}$ & 308,8 & 678,4 & 1534,8 & 2702,3 & 4183,6 & 4363,6 & 5204,1 \\
\hline $\begin{array}{l}\text { Доля ВРП ДВ } \\
\text { в ВВП РФ, \% }\end{array}$ & 5,4 & 4,9 & 4,5 & 5,4 & 6,0 & 5,8 & 6,1 \\
\hline
\end{tabular}

Высокие темпы роста валового регионального продукта (5 - 6 \% в год) Дальний Восток демонстрировал в 2010 - 2011 годы, что было связано преимущественно с масштабными государственными инвестициями в инфраструктуру для подготовки саммита в рамках форума «Азиатскотихоокеанское экономическое сотрудничество», состоявшегося в 2012 году в г. Владивостоке.

Отметим, что в 2018 году валовый региональный продукт Дальнего Востока составил 5,2 трлн. рублей, или 6,1 \% совокупного валового регионального продукта субъектов Российской Федерации, что выше уровня 2000 года на 0,7 процентных пункта.

В период 2012 - 2017 годов валовый региональный продукт Дальнего Востока не изменился, то есть в реальном выражении остался на уровне 2011 года. Это связано со значительным снижением инвестиций в указанный период на 26 \%. Этот тренд переломлен в 2017 году, когда в макрорегионе возобновился инвестиционный рост. Кроме того, в 2012 - 2017 годах произошло значительное снижение добавленной стоимости в строительном секторе Дальнего Востока на $27 \%$, который обладает большим мультипликативным эффектом для местной экономики.

Рассмотрим структуру валового регионального продукта по субъектам ДФО РФ (табл. 2).

В 2018 г. 73,2 \% созданного на территории ДФО ВРП приходилось на четыре субъекта: Республику Саха (Якутия), Сахалинскую область, Приморский и Хабаровский края. 
Таблица 2 - Структура ВРП в основных ценах по субъектам ДФО в 2018 г.

\begin{tabular}{|l|c|c|}
\hline \multicolumn{1}{|c|}{ Субъект РФ } & ВРП, млн. руб. & Удельный вес, \% \\
\hline Дальневосточный федеральный округ & 5204116,8 & 100,0 \\
\hline Республика Бурятия & 226134,7 & 4,3 \\
\hline Республика Саха (Якутия) & 1084556,2 & 20,8 \\
\hline Забайкальский край & 326865,7 & 6,3 \\
\hline Камчатский край & 236483,5 & 4,5 \\
\hline Приморский край & 834023,4 & 16,0 \\
\hline Хабаровский край & 710639,6 & 13,7 \\
\hline Амурская область & 301069,4 & 5,8 \\
\hline Магаданская область & 170723,4 & 3,3 \\
\hline Сахалинская область & 1179668,7 & 22,7 \\
\hline Еврейская автономная область & 55808,8 & 1,1 \\
\hline Чукотский автономный округ & 78143,4 & 1,5 \\
\hline
\end{tabular}

Сравнивая регионы по показателю среднедушевого значения ВРП, стоит учитывать большое количество факторов, в частности: сформировавшаяся отраслевая специализация регионального хозяйства; возможное влияние органов государственной власти и управления (наличие в северных и приравненных к ним территориях повышающего коэффициента к окладам работников, отражающегося на удорожании труда как фактора создания ВРП). По этому показателю Дальневосточный регион занимает четвертое место среди всех федеральных округов.

Факторами, сдерживающими социально-экономическое развитие Дальнего Востока в сравнении с Российской Федерацией в целом, являются:

1. сокращение численности населения в результате продолжающегося миграционного оттока. За 27 лет численность населения сократилась в 1,3 раза - с 10,5 млн. человек в 1991 году до 8,2 млн. человек в 2019 году;

2. продолжительность жизни меньше на 3,1 года;

3. низкий уровень обеспеченности транспортной и социальной инфраструктурами. Так, плотность автомобильных дорог общего пользования с твердым покрытием в 5,2 раза ниже; доля ветхого и аварийного жилья в 2,5 раза выше средних значений по Российской Федерации, а ввод жилья в 1,5 раза ниже;

4. высокие тарифы на энергетические ресурсы и услуги инфраструктурных компаний

Как видно, проводимая ранее органами государственной власти региональная экономическая политика не вывела экономику макрорегиона на темпы роста, превышающие среднероссийский уровень, и не предотвратила утечку кадров в более развитые регионы страны.

Осознавая масштаб происходящих в регионе разрушительных процессов, российское правительство в последние десять лет активно осуществляет политику модернизации и технологического обновления всей социально-экономической системы Дальнего Востока при использовании 
потенциала инвестиционного сотрудничества со странами АТР на основе повышение инвестиционной привлекательности региона.

Целью новой национальной программы «Социально-экономическое развитие Дальнего Востока на период до 2024 года и на перспективу до 2035 года» является обеспечение темпов экономического роста и показателей экономического развития Дальнего Востока, превышающих среднее значение по Российской Федерации. Реализация этой цели возможна за счет значительного наращивания частных инвестиций в новые производства с высокой добавленной стоимостью, модернизацию предприятий обрабатывающей промышленности, транспортный и строительный комплекс макрорегиона, государственных инвестиций - в магистральную, трансграничную, обеспечивающую и социальную инфраструктуры за счет значительного наращивания несырьевого экспорта и повышения производительности труда.

Поэтому в новой программе, определены следующие цели социальноэкономического развития Дальнего Востока:

1. на период до 2024 года включительно:

- превышение среднероссийских темпов роста показателей качества жизни населения, в том числе по таким основным направлениям, как повышение ожидаемой продолжительности жизни не менее чем на 5 лет, снижение смертности населения трудоспособного возраста не менее чем на 35 процентов, увеличение годового объема жилищного строительства в 1,6 раза;

- превышение среднероссийских темпов роста показателей экономического развития, в том числе за счет увеличения объема накопленных частных инвестиций до 800 млрд. рублей, создания не менее 200 предприятий на территориях опережающего развития и в свободном порту Владивосток, а также не менее 30 тыс. новых рабочих мест;

2. на период до 2035 года:

- прекращение миграционного оттока населения;

- превышение среднероссийских показателей качества жизни населения;

- превышение среднероссийских показателей экономического развития.

Увеличение количества инвестиций в основной капитал обеспечит инвестиционные прорыв в развитии Дальневосточного региона. Рассмотрим участие регионов в формировании инвестиций в основном капитале ДФО (табл. 3).

Таблица 3 - Инвестиции в основной капитал, в млн. руб.

\begin{tabular}{|l|c|c|c|c|}
\hline \multicolumn{1}{|c|}{ Регион } & 2015 г. & 2016 г. & 2017 г. & 2018 г. \\
\hline $\begin{array}{l}\text { Дальневосточный } \\
\text { федеральный округ }\end{array}$ & 1017589 & 1119924 & 1288173 & 1394467 \\
\hline Республика Бурятия & 36220 & 33445 & 42214 & 48754 \\
\hline Республика Саха (Якутия) & 198032 & 275576 & 386790 & 403427 \\
\hline Забайкальский край & 76282 & 85702 & 96324 & 90058 \\
\hline Камчатский край & 22850 & 37298 & 39007 & 39279 \\
\hline Приморский край & 139208 & 130500 & 130935 & 141859 \\
\hline Хабаровский край & 114008 & 120091 & 121185 & 129646 \\
\hline
\end{tabular}




\begin{tabular}{|l|c|c|c|c|}
\hline Амурская область & 102214 & 129816 & 192469 & 239705 \\
\hline Магаданская область & 60666 & 41798 & 43892 & 51512 \\
\hline Сахалинская область & 241464 & 240011 & 211815 & 218339 \\
\hline $\begin{array}{l}\text { Еврейская автономная } \\
\text { область }\end{array}$ & 12012 & 12929 & 11042 & 16821 \\
\hline Чукотский автономный округ & 14633 & 12757 & 12500 & 15068 \\
\hline
\end{tabular}

Анализируя данные таблицы 3 видно, что высокий уровень участия в капитале достигается за счет инвестиций в проекты Сахалинской области, а точнее сахалинских углеводородных проектах (почти «90 \% накопленных в данном регионе ПИИ концентрируется в сфере добычи природных ресурсов и геологоразведки). Это определяет ограниченное влияние прямых иностранных инвестиций на динамику и структуру экономики региона.

Традиционно определенную инвестиционную активность проявляют представители Республики Корея, а именно - корпорация «Hyundai Corporation», «LG Electronics», группа компаний «Samsung» и целый ряд других компаний.

В 2017 году во Владивостоке между Российской Федерацией и Республикой Корея был подписан пакет документов: меморандум о взаимопонимании между Фондом "Росконгресс" и Корейским агентством по содействию торговле и инвестициям, меморандум о взаимопонимании между Фондом развития Дальнего Востока и Байкальского региона и Экспортноимпортным банком Республики Кореи.

По информации «Корпорации развития Дальнего Востока», по состоянию на 15 апреля 2020 года в экономике Приморского края в стадии реализации находится 85 проектов (ТОСЭР и СПВ), осуществлённые иностранные инвестиции в которые составили 11 млрд. 784 млн. 470 тыс. 916 рублей. При этом общий плановый объём иностранных инвестиций по соглашениям должен составить 143 млрд. 213 млн. 841 тыс.18 рублей.

Республика Корея является одной из ведущих стран АТР инвесторов в Приморском крае.

По своему местоположению Приморский край имеет высокий экспортный потенциал и занимает позицию транзитного экспортного хаба для России на Дальнем Востоке. Большая часть экспорта - это транзитные грузы из российских регионов в страны АТР. Приморский край, в основном, экспортирует: рыбную продукцию, нефтепродукты, изделия из древесины и металлы (в совокупности они составляют почти 90\% экспорта). При этом основная доля экспорта приходится на: Китай, Республику Корею и Японию. В совокупности они составляют более 90\% внешних продаж Приморского края и демонстрируют стабильный рост в объемах экспорта в среднем на 12$16 \%$ в год.

По состоянию на 15 апреля 2020 года фактически осуществлённые корейские инвестиции в проекты, реализуемые в Приморском крае в рамках Свободного порта Владивосток (СПВ) и территорий опережающего социально-экономического развития (ТОСЭР), составили 674 млн. 607 тыс. рублей, или 5,7 \% от всех осуществлённых иностранных инвестиций. 
При этом объём корейских инвестиций по соглашениям (СПВ и ТОСЭР) составляет 8 млрд. 21 млн. 624 тыс. 193 рубля.

Резидентами Свободного порта Владивосток (Приморский край) являются 8 южнокорейских компаний, резидентами ТОСЭР Приморского края - 3 компании.

В результате, по количеству размещённых и уже утвержденных инвестиционных проектов, Приморский край занимает первое место среди регионов Дальневосточного Федерального округа ${ }^{1}$.

В 2016 году завершено строительство 2 объектов инфраструктуры и завершены работы по проектированию 33 объектов, начато проектирование по 37 объектам, строительно-монтажные работы начаты на 12 объектах.

В общей сложности благодаря реализации данных проектов будет создано более 2 тысяч новых рабочих мест, что в значительной степени улучшит благосостояние региона и его жителей.

Таким образом, сотрудничество с зарубежными партнерами и реализация иностранных бизнес-проектов благоприятно влияют на инвестиционный климат ДФО путем создания новых рабочих мест, привлечением высококвалифицированных, а также обучением отечественных специалистов, новых и инновационных технологий.

\section{Список литературы.}

1. Инвестиционная карта [Электронный ресурс] // Инвестиционный портал Приморского края. https://invest.primorsky.ru/ru/guide/ investment-map (Дата обращения 03.11.2020).

2. Латкин А.П., Пяо Ихуа, Чжон Мен Су. Современный подход к совершенствованию системы управления рисками сельскохозяйственного предпринимательства // Территория новых возможностей. Вестник Владивостокского государственного университета экономики и сервиса. 2019. T. 11. № 1. С. 59-73.

3. Латкин, А. П., Харченкова, Е. В. Дальневосточный регион: перспективы инновационного прорыва // Территория новых возможностей. Вестник Владивостокского государственного университета экономики и сервиса, 2019 №11(1). С. 6-16.

4. Ли М., Латкин А.П. Воздействие российско-китайского сотрудничества на предпринимательский сектор Приморского края // Экономика: вчера, сегодня, завтра. 2019. Т. 9. № 8-1. С. 149-157.

5. Минакир П.А. Прямые иностранные инвестиции в экономике российского Дальнего Востока // Экономические и социальные перемены:

\footnotetext{
${ }^{1}$ Инвестиционная карта [Электронный ресурс] // Инвестиционный портал Приморского края. - Режим доступа: https://invest.primorsky.ru/ru/guide/ investment-map (Дата обращения 03.10.2020).
} 
факты, тенденции, прогноз. 2018. № 3. С. 41-56.

6. Национальная программа «Социально-экономическое развитие Дальнего востока на период до 2024 года и на перспективу до 2035 года»: Распоряжение Правительства Российской Федерации от 24 сентября 2020 года № 2464-p. - [Электронный ресурс]. - Режим доступа: http://static.government.ru/media/files/NAISPJ8QMRZUPd9LIMWJoeVhn1l6eGqD.pdf

7. Трофименкова Е.В. Инновационное управление развитием инфраструктуры сельских территорий // Современные научные исследования: актуальные теории и концепции. 2020. С. 268-272.

8. Чжон Мен Су. Треугольник возможностей: Бизнес в рамках «Новой Северной политики». PUBPLE. 2019.

9. Jeon Myong Su, Trofimenkova E.V. Strategy for international economic cooperation of Russia with states North-east Asia [Electronic resource] // Crossborder economy. Vladivostok, 2020. Ch.4. URL: http://crossbordereconomy.ru/6 arhiv.html. 